\title{
The Content of the Psychological Work Contract for Frontline Police Officers
}

\author{
Donald A.J. Cable \\ The University of Waikato, New Zealand
}

\begin{abstract}
Adding to the field of knowledge on the content of the psychological work contract, structured interviews with 35 frontline police officers generated 662 responses relating to the content of the psychological work contract for this employment sector. Analysis of these responses resulted in the development of an initial two-component measure of the contract. One component ( 17 items) reflected the obligations arising from the promises officers believed the organisation had made to them. The other component ( 19 items) reflected the obligations arising from the promises officers believed they had made to the organisation. The measure was included in a survey completed by 84 frontline police officers. Factor analysis revealed two factors in each component. For the organisation's obligations component, one factor reflected obligations related more to the organisational environment, whereas the other factor reflected obligations related more to the job environment. For the employee's obligations component, one factor reflected obligations related more to behaviours on the job, whereas the other factor reflected obligations related more to the pursuit of development opportunities. The nature of the relationships that emerged between the psychological contract and the nomological network variables included in the study provide strong support for the validity of this measure of the psychological contract.
\end{abstract}

- Keywords: psychological contract, measure development, construct validation

There have been calls for research into the psychological contract to be grounded in a common understanding as to exactly what the psychological contract is (see, e.g., Conway \& Briner, 2005). As Conway and Briner noted, the psychological contract, like many ideas in the social sciences, lacks an agreed definition. However, reinforced somewhat by their work, there is growing acceptance that the psychological contract evolves from the implicit and explicit promises that are made, or are perceived to be made, between the individual and the organisation. Although definitions of the contract often include the terms 'obligations' and 'expectations', Conway and Briner argued that these terms should only be considered a part of the contract if they are based on, or arise from, a perceived promise. This reinforces Rousseau's definition of the contract as 'an individual's beliefs regarding the terms and conditions of a reciprocal exchange agreement', adding that one of the key issues is 'the belief that a promise has been made and a consideration offered in exchange for it' (1989, p. 123, emphasis added).

Conway and Briner (2005) suggested three general areas - content, breach, process - in which ongoing re- search into the psychological contract could be focused. The first two areas are relevant to this study. They noted that 'relatively few studies have been conducted in this [content] area' (p. 38). Content is an area that has been relatively neglected, with researchers developing measures ad hoc and not necessarily confirming with any scientific rigour the reliability or validity of such measures. Breach - and/or violation - or conversely fulfilment, has received more attention because it is directly relevant to the employment relationship. The present study focused firstly on the content of psychological contracts and from this focus a measure of the contract was developed. In the second phase of the research, in which construct validity was assessed, the focus shifted to an assessment of fulfilment of the contract utilising the measure developed in the first phase.

ADDRESS FOR CORRESPONDENCE: Donald Cable, The University of Waikato, Private Bag 3105, Hamilton, New Zealand. Email: dcable@waikato.ac.nz 
Psychological contracts are proposed to vary across several factors (Dabos \& Rousseau, 2004; McLean Parks, Kidder, \& Gallagher, 1998; Rousseau \& Tijoriwala, 1998; Thomas, Au, \& Ravlin, 2003), with Muchinsky (2006) suggesting that the globalisation of business, including global labour markets, will also bring an evolutionary focus on cultural differences in the development and management of the psychological contract. Beyond cultural differences, factors such as employment level or sector are also proposed to influence content. These potential variances in psychological contract content reinforce the importance of researching the specific content of psychological contracts for different employment groups and environments, hence the focus of this research on the specific employment sector of frontline police officers. The decision to focus on frontline police officers was largely pragmatic, but provided the basis for the comparison of this population to another (see Cable, 2010). A review of published research also revealed that no measure of the psychological contract appears to have yet been developed specifically for frontline police officers.

Any attempt to define the content of a generic psychological contract could fail to recognise the many factors that influence individual contracts. For example, an entry-level factory worker would have different expectations of, and perceive different obligations from, their organisation than a senior manager in a commercial organisation (Herriot \& Pemberton, 1997). The likelihood is that a factory worker's psychological contract would be more transactional in nature, with the content reflecting the immediate nature of the employment relationship and more concerned with self-interest. In contrast, a senior manager's psychological contract would likely be more relational in nature, with the content reflecting the ongoing relationship between them and the organisation. A generic measure of the psychological contract has the potential to omit important content relevant to specific employment groups. Only by exploring the content of the contract for disparate groups of employees will the importance of this potential omission be reinforced.

The present study involved two phases using the methodology adopted by Cable (2010). In Study 1, involving qualitative interviews, a measure of the psychological contract for frontline police officers was developed. In Study 2, the measure developed in Study 1 was included in a questionnaire that was completed by officers. To explore construct validity, the data from Study 2 were subjected to factor and reliability analyses resulting in the development of a four-component final measure of the psychological contract for police officers. This measure was subsequently embedded in a nomological network of other organisational psychological variables. A nomological network is the end result of a process known as construct explication and provides a detailed description of the relationships that are proposed to exist between the construct being validated and other constructs or be- haviours (Murphy \& Davidshofer, 1998). The extent to which the relationships predicted in the nomological network are found provides support for construct validity.

\section{Study I: Developing the Measure}

Study 1 focused on the development of a measure of the psychological contract. Although Anderson and Schalk (1998), supported by Cavanaugh and Noe (1999), suggested that most employees are able to describe the content of their contract, they argued that there is no real consensus about what the psychological contract is or what it actually encompasses. Both Kotter (1973) and Sims (1994) proposed that the psychological contract may literally contain thousands of items, and therefore making a complete list would be impracticable, if not impossible. From this pool of 'thousands of items', individuals draw specific and relevant items, grouping them into higher level and broader categories or classes, to form the content of their own idiosyncratic psychological contract. The concept of grouping items into higher level and broader categories or classes to form a measure of the psychological work contract was the methodological approach adopted in this study.

As the psychological contract is very much an individual construction or perception (Rousseau, 1989; Rousseau \& Tijoriwala, 1998), directly asking officers what they believed was in their contract was accepted as a valid approach to determining content. This approach was reinforced by Rousseau and Tijoriwala (p. 681, emphasis added) who commented that 'Subjective or self-reported measures are the most direct source of information on the nature and content of the psychological contract'. Accordingly, rather than developing a measure of the psychological contract based on a priori conceptualisations, an inductive approach was adopted in which items were elicited from participants ensuring, as much as practicable, the measure reflected individuals' beliefs regarding the content of their contracts.

\section{Method}

\section{Participants}

The names of 50 New Zealand (NZ) police officers were provided to the researcher by the organisation. The selection of these names was at the discretion of the organisation, based on the criterion that the names provided be of currently serving frontline police officers. Of the 50 officers contacted by the researcher, 35 participated in the interviews. Of these 35 officers, 51\% were aged $30-40,74 \%$ were male, $83 \%$ were married or living as married, and 91\% described themselves as being of European descent. Average length of service was 11 years $(S D=9.3)$. 


\section{Procedure}

Transcripts of the structured interviews, which lasted 30-40 minutes, were submitted to participants who requested the opportunity to verify their responses. All participants in this phase of the study agreed to participate in the second phase of the research and their details were recorded to facilitate this.

\section{Measures}

Utilising a structured interview form (Cable, 2010) and one-on-one, face-to-face interviews, officers were asked for their views on the content of their psychological work contract. They were requested to focus specifically on the promises, and the expectations arising from those promises, that were not included or covered in their formal written employment contract. Acknowledging the mutuality inherent in the psychological contract, the individual and the organisation, participants were asked to reflect upon two perspectives. The first perspective focused on what they believed the organisation had promised them and what they believed the organisation expected from them in return for the organisation keeping those promises. The second perspective focused on what they believed they had promised the organisation, and what they expected from the organisation in return for them keeping that promise. Participants were asked to rate, on a 5-point scale $(1=$ Not important, $5=$ Extremely important), how important each promise/expectation was to them. Each set of four questions, promise/importance and expectation/importance, for both perspectives, was repeated until participants felt satisfied that they had raised all relevant promises/expectations.

\section{Results}

The 662 interview responses were subjected to a content analysis process undertaken with the support of two subject matter experts (SME). The SMEs were each provided with the complete list of the responses with the instruction to review them and to create categories or classes that described, or reflected at a broader or higher level, the promise or expectation identified in each response. The SMEs were then instructed to assign each response to one of the categories they had created. The responseto-category assignments from each SME were combined into a single list without any alteration so that the category for which the categories and response assignments that each SME had made could be directly compared. The SMEs reviewed the single list and decided which categories and response assignments more accurately reflected the intent of the promise or expectation, before they met with the researcher for the final analysis.

In the final analysis, any responses for which consensus between the SMEs had not been found, or which remained unallocated, were discussed between the SMEs and the researcher and, upon agreement, these responses
TABLE I

Factor Loadings: The Organisation's Obligations

\begin{tabular}{|c|c|c|c|}
\hline Item no. & Item description & Factor I & Factor 2 \\
\hline 1 & $\begin{array}{l}\text { Provide an interesting and satisfying } \\
\text { job }\end{array}$ & -.10 & .70 \\
\hline 2 & Provide job security & .00 & .48 \\
\hline 3 & $\begin{array}{l}\text { Foster a sense of family/belonging } \\
\text { within the organisation }\end{array}$ & .04 & .82 \\
\hline 4 & Support you in your job at all times & .56 & .23 \\
\hline 5 & $\begin{array}{l}\text { Provide career development advice } \\
\text { and opportunities (item deleted) }\end{array}$ & & \\
\hline 6 & $\begin{array}{l}\text { Provide personal development advice } \\
\text { and opportunities }\end{array}$ & .44 & .34 \\
\hline 7 & Create a safe working environment & .72 & .16 \\
\hline 8 & $\begin{array}{l}\text { Provide a fair remuneration/benefits } \\
\text { package }\end{array}$ & .67 & .05 \\
\hline 9 & $\begin{array}{l}\text { Allow you to maintain a personally } \\
\text { acceptable work/life balance }\end{array}$ & .54 & .21 \\
\hline 10 & $\begin{array}{l}\text { Provide the necessary equipment } \\
\text { and resources to do the job }\end{array}$ & .72 & -.15 \\
\hline 11 & $\begin{array}{l}\text { Treat you fairly, equitably, and with } \\
\text { respect }\end{array}$ & .72 & -.15 \\
\hline 12 & Foster team cohesiveness & .63 & .17 \\
\hline 13 & $\begin{array}{l}\text { Provide feedback on your level of } \\
\text { contribution to the organisation }\end{array}$ & .71 & .20 \\
\hline 14 & $\begin{array}{l}\text { Maintain high ethics in the } \\
\text { employee-employer relationship }\end{array}$ & .77 & -.21 \\
\hline 15 & $\begin{array}{l}\text { Communicate openly and honestly } \\
\text { on all matters that affect you }\end{array}$ & .81 & -.19 \\
\hline 16 & Demonstrate strong leadership & .78 & -.13 \\
\hline \multirow[t]{3}{*}{17} & $\begin{array}{l}\text { Ensure the welfare of yourself and } \\
\text { your family }\end{array}$ & .46 & .37 \\
\hline & Eigenvalues & 6.47 & 2.26 \\
\hline & Percent variance explained & 37.28 & 11.09 \\
\hline
\end{tabular}

Note: Factor correlation: $r=.68, p<.01$.

were either allocated to an existing category or allocated to a new category. The end result of this process was that all 662 responses were allocated to a category. As a final step in the process, and where there was agreement between the SMEs and the researcher, categories which were perceived to reflect the same content were merged with each other, thus eliminating duplicate categories.

The analysis of the interview responses resulted in the production of a preliminary list of 43 categories. However, categories which contained fewer than five responses were deleted as these were considered to be less important due to the highly idiosyncratic nature of the items in those categories. This reduced the final number of categories - now termed items - to 36, with 17 representing the promises officers believed the organisation had made to them, and the expectations they had of the organisation (see Table 1, Study 2 results), and 19 representing the promises officers believed they had made to the 


\section{TABLE 2}

Factor Loadings: Employee Obligations

\begin{tabular}{|c|c|c|c|}
\hline Item no. & Item description & Factor I & Factor 2 \\
\hline 1 & $\begin{array}{l}\text { Pursue career development } \\
\text { opportunities }\end{array}$ & -.01 & .84 \\
\hline 2 & $\begin{array}{l}\text { Pursue personal development } \\
\text { opportunities }\end{array}$ & -.11 & .81 \\
\hline 3 & Pursue training opportunities & .15 & .66 \\
\hline 4 & $\begin{array}{l}\text { Actively apply new } \\
\text { training/development to the job }\end{array}$ & .46 & .38 \\
\hline 5 & $\begin{array}{l}\text { Embrace and support the team } \\
\text { environment }\end{array}$ & .60 & .15 \\
\hline 6 & $\begin{array}{l}\text { Perform your job to your utmost } \\
\text { ability }\end{array}$ & .73 & -.14 \\
\hline 7 & $\begin{array}{l}\text { Communicate openly on any } \\
\text { employment matters }\end{array}$ & .67 & .08 \\
\hline 8 & $\begin{array}{l}\text { Treat others in the organisation } \\
\text { fairly and equitably }\end{array}$ & .89 & -.14 \\
\hline 9 & $\begin{array}{l}\text { Be loyal and committed to the } \\
\text { organisation }\end{array}$ & .51 & .08 \\
\hline 10 & $\begin{array}{l}\text { Act professionally at all times, on } \\
\text { and off duty (item deleted) }\end{array}$ & & \\
\hline II & $\begin{array}{l}\text { Maintain a high level of personal } \\
\text { ethics and integrity }\end{array}$ & .81 & -.06 \\
\hline 12 & $\begin{array}{l}\text { Actively engage in the health and } \\
\text { safety of self and others }\end{array}$ & .79 & -.12 \\
\hline 13 & $\begin{array}{l}\text { Subscribe to the organisation's } \\
\text { culture, values, and norms (item } \\
\text { deleted) }\end{array}$ & & \\
\hline 14 & Maintain a community focus & .48 & .22 \\
\hline 15 & Act as a role model to others & .42 & .27 \\
\hline 16 & $\begin{array}{l}\text { Adhere to established practices and } \\
\text { procedures (item deleted) }\end{array}$ & & \\
\hline 17 & $\begin{array}{l}\text { Use available resources and } \\
\text { equipment appropriately }\end{array}$ & .75 & .04 \\
\hline 18 & $\begin{array}{l}\text { Maintain a high level of work ethic } \\
\text { and integrity }\end{array}$ & .84 & -.07 \\
\hline \multirow[t]{3}{*}{19} & $\begin{array}{l}\text { Be flexible in availability for work } \\
\text { (Item deleted) }\end{array}$ & & \\
\hline & Eigenvalues & 6.62 & 2.11 \\
\hline & Percent variance explained & 41.06 & 11.46 \\
\hline
\end{tabular}

Note: Factor correlation: $r=.30, p<.01$.

organisation, and the expectations they believed the organisation had of them (see Table 2, Study 2 results).

The means and standard deviations for the ratings of importance for the responses in each item were assessed. The mean level of importance for all items ranged from 4.4 to 4.5 on the 5-point scale, midway between Very and Extremely important. All 36 items were therefore retained in the development and validation of the final measure. These items are now collectively referred to as obligations, based on the argument that obligations arise from both promises and expectations.

\section{Discussion}

Study 1 developed a measure covering the content of the psychological work contract for frontline police officers. The primary validation concern in Study 1 was to establish content validity (Freese \& Schalk, 2008), defined by Westen and Rosenthal (2003) as the extent to which the measure adequately samples the content of the domain that constitutes the construct', (p. 609, emphasis added). The degree to which content validity may be confirmed is limited, for as Murphy and Davidshofer (1998) argued, this cannot be measured or assessed by a single statistic. Referencing Guion (1977), Murphy and Davidshofer reinforced the definition of Westen and Rosenthal, by proposing that content validity 'represents a judgement regarding the degree to which a test provides an adequate sample of a particular content domain' (p. 151, emphasis added) and they described a basic procedure for establishing this, although also claiming that, in practice, this procedure is difficult to implement. One may, however, make an informed assessment of the degree of compliance achieved with each of the steps involved in the procedure proposed by Murphy and Davidshofer and argue with some confidence that content validity has been achieved.

The steps in Murphy and Davidshofer's (1998) procedure involves describing the content domain, determining the areas of the content domain that are measured by each test item, and a comparison between the structure of the measure and the structure of the content domain. Based on definitions of content validity (Jewel, 1998; Westen \& Rosenthal, 2003), and adherence to the procedure for establishing content validity (Murphy \& Davidshofer), the measure of the psychological contract developed thus far provides an adequate measure of that construct and possesses an acceptable level of content validity. Taking this measure to the next step in the process was therefore a justifiable decision insofar as content validity was concerned.

\section{Study 2: Validating the Measure}

Validation of the measure of the psychological contract developed in Study 1 was approached through the construction and application of a nomological network. A nomological network may be described as a network of relationships that describe rules of reasoning and is the end result of a process known as construct explication which provides a detailed description of the relationships that are proposed to exist between the construct being validated and other constructs or behaviours (Murphy \& Davidshofer, 1998). The objective is to embed the construct being validated into the nomological network of other variables and to test the hypothesised relationships, that is the rules of reasoning, between those variables (Cronbach \& Meehl, 1955, cited in Westen \& Rosenthal, 2003). Many of the variables in the 
nomological network, including job satisfaction, intention to quit, organisational commitment, personorganisation fit, and perceived organisational support, have been included in previous research into the psychological contract (Conway \& Briner, 2002; Coyle-Shapiro \& Kessler, 2000), and have also been explored within the framework of a nomological network involving the psychological contract (Rousseau, 1998), and therefore provided a logical and sound framework for validation. Other variables, including career plateau, and both job and work involvement, were including to increase the validity of the nomological network.

The measure of the psychological contract was included in a survey questionnaire containing the following nomological network variables:

Career plateau. 'That point where it becomes painfully evident that further job advancement is blocked for any or all of a variety of reasons ...' (Kelly, 1985, p. 65). The premise was that, if officers believed their careers had plateaued, they may potentially attribute their career status to the organisation not fulfilling its obligations, or meeting their expectations, under the terms of the psychological contract. Based on this premise, higher perceptions of career plateau are likely to result in a greater awareness of the psychological contract, with the belief that the organisation is not fulfilling it. Although career plateau may be positive (Ettington, 1998), the potential also exists that if an individual perceives themself as experiencing a career plateau, they may feel less obligated or motivated to meet the expectations the organisation has of them. Based on these arguments, the nomological network implies that:

1. Career plateau will be negatively related to perceptions that the organisation is fulfilling its obligations under the psychological contract.

2. Career plateau will be negatively related to the individual fulfilling their obligations under the psychological contract.

Intention to quit. 'Turnover intention ... a conscious and deliberate wilfulness to leave the organisation. ... the strongest cognitive precursor of turnover' (Tett \& Meyer, 1993, p. 259). The basic premise was that, if officers were intending to quit their job, they would be less likely to be fulfilling their obligations under the terms of the psychological contract. A high intention to quit suggests a low commitment to the employment relationship. Based on this premise, higher levels of intention to quit in individuals are likely to result in less commitment to fulfilling their obligations under the psychological contract, given that they are intending to terminate their employment. The corollary to this is that, if officers perceive that the organisation is not fulfilling its obligations under the psychological contract their intention to quit will be higher. Based on these arguments, the nomological network implies that:

3. Intention to quit will be negatively related to perceptions that the organisation is fulfilling its obligations under the psychological contract.

4. Intention to quit will be negatively related to the individual fulfilling their obligations under the psychological contract.

Organisational commitment. 'The strength of an individual's identification with and involvement in a particular organisation' (Porter, Steers, Mowday, \& Boulian, 1974, as cited in Bozeman \& Perrewe, 2001, p. 161). The proposition was that if officers were strongly committed to the organisation, they would expect a similar level of commitment from the organisation. This proposition leads to the expectation of higher levels of organisational commitment being related to the commitment by individuals to fulfil their obligations under the terms of the psychological contract. Additionally, and accepting the norm of reciprocity, the extent to which the organisation is acknowledged as fulfilling the psychological contract is likely to be rated higher by individuals with a stronger commitment to the organisation. Based on these arguments, the nomological network implies that:

5. Organisational commitment will be positively related to perceptions that the organisation is fulfilling its obligations under the psychological contract.

6. Organisational commitment will be positively related to the individual fulfilling their obligations under the psychological contract.

Job involvement. 'The extent to which the individual sees his/her job as important to his/her self-image. ... the importance of one's job to one's self-image' (Blau, 1987, p. 243). The proposition was that if officers identified strongly with their job, and were consequently highly involved in that job, they would be more likely to be fulfilling their obligations, under the terms of the psychological contract. High job involvement suggests the likelihood of a correspondingly high commitment to the employment relationship. Accepting this proposition, individuals expressing high levels of job involvement are also likely to confirm a commitment to that relationship by fulfilling their obligations under the psychological contract. Based on this argument, the nomological network implies that:

7. Job involvement will be positively related to the individual fulfilling their obligations under the psychological contract.

Perceived organisational support (POS). 'To meet socioemotional needs and to determine the organisation's readiness to reward increased work effort, employees develop global beliefs concerning the extent to which the 
organisation values their contributions and cares about their wellbeing (POS)' (Eisenberger, Stinglhamber, Vandenberghe, Sucharski, \& Rhoades, 2002, p. 565). The basic premise was that if officers perceived high levels of support from the organisation, they would be more likely to be meeting the expectations they believed the organisation had of them, under the terms of the psychological contract. High perceptions of organisational support suggest the likelihood of a correspondingly high level of individual commitment to the employment relationship, reinforced by a willingness on the part of the individual to fulfil their obligations under the psychological contract. Based on these arguments, the nomological network implies that:

8. Perceived organisational support will be positively related to perceptions that the organisation is fulfilling its obligations under the psychological contract.

9. Perceived organisational support will be positively related to the individual fulfilling their obligations under the psychological contract.

Job satisfaction. That state which results from 'the appraisal of one's job as attaining or allowing the attainment of one's important job values, providing these values are congruent with or help to fulfil one's basic needs' (Locke, 1983 , p. 1319). The basic premise was that if officers were satisfied with their job, they would be more likely to believe that they were obligated to meet the expectations they believe the organisation has of them, under the terms of the psychological contract. High levels of job satisfaction suggest the likelihood of a correspondingly high commitment by the individual to the employment relationship reinforced also through a commitment by them to fulfilling their obligations under the psychological contract. Based on these arguments, the nomological network implies that:

10. Job satisfaction will be positively related to perceptions that the organisation is fulfilling its obligations under the psychological contract.

11. Job satisfaction will be positively related to the individual fulfilling their obligations under the psychological contract.

Person-organisation fit (POF). 'The compatibility between people and organisations that occurs when: (a) at least one entity provides what the other needs, or (b) they share similar fundamental characteristics, or (c) both' (Kristof, 1996, p. 4). If officers perceived that the degree of fit they had with the organisation was high, the proposition is that they would expect the organisation to acknowledge this fit in various ways, as they in turn would. This acknowledgment is proposed to manifest in fulfilment of the psychological contract, with individuals fulfilling their obligations and perceiving the organisa- tion as doing the same. Based on these arguments, the nomological network implies that:

12. Person-organisation fit will be positively related to perceptions that the organisation is fulfilling its obligations under the psychological contract.

13. Person-organisation fit will be positively related to the individual fulfilling their obligations under the psychological contract.

Work involvement. 'The beliefs that individuals have regarding the degree of importance that work plays in their lives' (Paullay, Alliger, \& Stone-Romero, 1994, p. 225). If work is important to officers, that is, they have what might be considered to be a high work ethic, the extent to which they believed they were obligated to the organisation, as per the terms of the psychological contract, would likely be rated higher by those officers. High work involvement potentially suggests the likelihood of a correspondingly high commitment to the employment relationship by individuals, reinforced by a strong commitment to meeting their psychological contract obligations. Accepting this proposition, individuals who express high work involvement are also likely to express high fulfilment of their obligations under the psychological contract. Based on these arguments, the nomological network implies that:

14. Work involvement will be positively related to the individual fulfilling their obligations under the psychological contract.

In summary, the nomological network predicted that if the employee believed the organisation was fulfilling the psychological contract: (a) positive and significant relationships would exist between the psychological contract and organisational commitment, perceived organisational support, job satisfaction and personorganisation fit; and (b) significant and negative relationships would exist between fulfilment of the psychological contract and career plateau and intention to quit. Additionally, the nomological network predicted that if the employee believed they were fulfilling the psychological contract: (a) positive and significant relationships would exist between the psychological contract and organisational commitment, job involvement, perceived organisational support, job satisfaction, personorganisation fit, and work involvement; and (b) significant and negative relationships would exist between fulfilment of the psychological contract and career plateau and intention to quit. Although a measure of trust was included, to assess the overall employment environment, this variable did not form part of the nomological network. 


\section{Method}

\section{Participants}

Invitations to participate in this phase of the research were issued to approximately 500 frontline police officers, with instructions to contact the researcher if they were willing to participate. Additionally, all 35 participants from the first phase of the study were contacted directly by the researcher. Despite follow-up actions, only $84 \mathrm{com}$ pleted questionnaires were received, yielding a $16 \%$ response rate. The mean age of participants was 42.5 years $(S D=8.5), 81 \%$ were male, $87 \%$ were married or living as married, and $86 \%$ described themselves as being of European descent. The average length of service was 16 years $S D=11.1$.

\section{Procedure}

The 84 participants were sent an email offering them the option to receive a hardcopy version of the questionnaire (SAE provided), or to receive an email containing a link (URL) to an online version. Nine participants (11\%) elected to complete the hardcopy questionnaire. Utilising the two methods of data collection is unlikely to have influenced the results (Kickul \& Lester, 2001).

\section{Measures}

The Psychological Work Contract. The measure of the psychological contract developed in Study 1 was included in the survey. Participants were requested to state, for each obligation, the extent to which they believed it (a) existed and (b) was being fulfilled. The set of questions relating to the extent to which the obligation existed used the stem (Cable, 2010) 'To what extent do you believe the organisation has [you have] an obligation to ...' with responses rated on a 7-point scale anchored from $1=$ No extent to $7=$ Extreme extent. The set of questions relating to the extent to which the obligation was being fulfilled used the stem: 'To what extent do you believe the organisation is [you are] fulfilling their [your] obligation to ...' and used the same 7-point response scale.

Trust. Based on the argument that the process of psychological contract formation and fulfilment is more likely to have positive outcomes if an environment of trust prevails (Clinton \& Guest, 2004; Robinson, 1996), trust was assessed. Participants were asked whether or not they trusted their employer (Yes or No), and whether or not they believed their employer trusted them (Yes or No). Participants were also asked to rate how important it was for this trust to exist $(1=$ Not important to $4=$ Very important). The format of the questions was based on a review of relevant studies (Clark \& Payne, 1997; Korsgaard, Brodt, \& Whitener, 2002; Kramer, 1999) and the measurement of trust (Clinton \& Guest, 2004; Kessler \& Undy, 1996).
The response scales for all remaining measures were standardised and assessed on a 7-point scale anchored from $1=$ Strongly disagree to $7=$ Strongly agree .

Career plateau. To assess the extent to which participants believed they were experiencing career plateau, a measure constructed by Cable (1999) was utilised. Cable adopted two items from Chao (1990) and three items from Ettington (1998). The questions in the measure addressed the likelihood of the participant being promoted or getting ahead in the organisation and included such items as: 'I am not getting ahead in the organisation' and 'I expect to advance to a higher level in the near future in the organisation' $(a=.73)$.

Intention to quit. A five-item bank of questions, developed by Bozeman and Perrewe (2001), and based on the work of Mowday, Koberg, and MacArthur (1984), was used to assess participants' intention to quit $(a=.91)$. Containing both positively and negatively worded items, the measure included items such as 'I will probably look for a new job in the near future', and 'I do not intend to quit my job'. Bozeman and Perrewe reported coefficient alphas of .94 and .90 for two different samples in their study.

Organisational commitment. To assess organisational commitment the three component measure developed by Meyer and Allen (1997) was relied upon. Meyer and Allen reported median reliabilities for the affective (want to stay), continuance (have to stay), and normative (ought to stay) commitment components of .85, .79, and .73 respectively (present study $=.78, .81, .77$ respectively). The measure included items such as 'I really feel as if this organisation's problems are my own' and 'This organisation deserves my loyalty'.

Job involvement. Kanungo's (1982) original 10-item measure of job involvement was reduced to 9 for the present study by the removal of the negatively worded item 7 ('Usually, I feel detached from my job'). Paterson and O'Driscoll (1990) found this item reduced the internal consistency of the measure which when removed yielded an alpha for the measure of .85. The nine-item measure adopted for the present study $(\mathrm{a}=.85)$ included items such as 'To me, my job is only a small part of who I am' and 'Most of my personal life-goals are job-oriented'.

Perceived organisational support. Accepting the veracity of Eisenberger, Cummings, Armeli, and Lynch's (1997) work with the eight-item measure of perceived organisational support (POS), and its use in research by Lynch, Eisenberger, and Armeli (1999, $a=.90)$ and Rhoades, Eisenberger, and Armeli (2001, $a=.90)$, this measure of POS was accepted for the present study. The measure included items such as 'This organisation really cares about my well-being' and 'Help is available from this 
organisation when I have a problem' and, in this study, returned an alpha reliability coefficient of .86 .

Job satisfaction. The three-item Michigan Organisational Assessment Questionnaire (Cammann, Fichman, Jenkins \& Klesh, 1979, as cited in Cook, Hepworth, Wall, $\&$ Warr, 1981), was relied on for a measure of overall job satisfaction $(a=.81)$. Items in the measure included 'In general, I don't like my job' and 'All in all, I am satisfied with my job'.

Person-organisation fit. The three-item measure of person-organisation fit (POF) developed by Cable and Judge (1996, $\mathrm{a}=.87)$ was adopted for the present study $(a=.81)$, with the wording changed slightly to conform to the overall format of the questionnaire. For example, "To what degree do you feel your values "match" or fit this organisation and the current employees in this organisation?' was changed to 'My values "match" or fit those of the organisation' and 'My values "match" or fit those of current employees in the organisation'.

Work involvement. In conjunction with the development of the job involvement measure, Kanungo (1982) developed a six-item measure of work involvement $(a=.75)$ and this measure was adopted for the present study $(a=.79)$. The measure included items such as 'Work is only a small part of my job' and 'My personal life goals are work-oriented'.

\section{Results}

Trust. The level of trust prevailing at the time this research was conducted was assessed with the following results. Seventy-four per cent of the 83 participants who responded confirmed that they trusted the organisation and agreed that it was close to Very important to do so -3.8 on 4 -point scale. Conversely, $81 \%$ of the 75 participants who responded confirmed that they believed the organisation trusted them, also agreeing that it was Very important for the organisation to do so -3.9 on 4-point scale. Based on this analysis it was accepted that a reasonable level of trust prevailed and that could be interpreted as confirming that the content of the psychological contract was not subjected to any adverse employeremployee relationship influence.

\section{Factor analysis: Content of the psychological contract.}

The dimensionality and factor structure of the content measure was analysed using maximum likelihood factor analysis. As the measure of the psychological contract was a new measure, maximum likelihood factor analysis was considered appropriate to search for factors in the measure (Kline, 2000). Three criteria were used to determine the number of factors to rotate in the factor analysis: (a) the a priori hypothesis that each measure was unidimensional, (b) the eigenvalues, and (c) the interpretability of the solution (Hair, Anderson, Tatham, \& Black, 1995;
Kline). A factor loading criterion of 0.40 was accepted as confirming a significant loading.

Factor analysis: The organisation's obligations. The Kaiser-Meyer-Olkin Measure of Sampling Adequacy (KMO-MSA) for the 17 items reflecting the content of the psychological contract covering the obligations the organisation had to officers - now termed Organisation's Obligations — was .86 (Hair et al., 1995), and Bartlett's Test of Sphericity was significant, confirming that it was appropriate to continue with the analysis. Three initial factors with eigenvalues of $6.70,2.36$, and 1.36 were rotated, and as the factors were expected to be correlated, an oblimin (oblique) rotation procedure with Kaiser normalisation was used (Breakwell, Hammond, \& Fife-Schaw, 2000; Hair et al.). The final rotated solution, with item 5 deleted as it did not load significantly, yielded two interpretable factors accounting for 37.28 and 11.09 percent of the item variance respectively (Table 1$)$. The low ratio of cases to items $(84 / 17=4.9: 1)$ is a potential limitation (see Limitations). Factor 1 items (items 4, 6-17; Table 1) appear to relate to obligations that affect more directly the manner in which officers expect to be treated or supported by the organisation. This factor may be viewed as the organisational environment. Factor 2 items (items $1-3$; Table 1) appear to relate more to job conditions and the creation of an environment in which officers feel secure and satisfied in their jobs. Based on this analysis, two variables were constructed. The first variable, containing 14 items (Factor 1), was termed 'psychological contract organisational environment' (PC-OrgEnv, $a=.91$ ). The second variable, containing three items (Factor 2), was termed 'psychological contract - job environment' (PCJobEnv, $a=.73$ ).

Factor analysis: The employee's obligations. The KMO-MSA for the 19 items reflecting the content of the psychological contract covering the obligations officers had to the organisation - now termed Employee's Obligations - was .83 and Bartlett's Test of Sphericity was significant, confirming that it was appropriate to continue with the analysis. Five initial factors, with eigenvalues of $7.44,2.19,1.55,1.18$, and 1.02 , were rotated and as the factors were expected to be correlated, an oblimin (oblique) rotation procedure with Kaiser normalisation was used (Breakwell et al., 2000; Hair et al., 1995). The final rotated solution, with items 10,13 , 16 , and 19 removed as they either cross-loaded or did not load significantly, yielded two interpretable factors accounting for 41.06 and 11.46 percent of the item variance respectively (Table 2 ). The low ratio of cases to items $(84 / 19=4.4: 1)$ is a potential limitation (see Limitations). Factor 1 items (items 4-9, 11-12, 14-15, 1718; Table 2) appear to relate more to obligations officers believe they have with regards to the way they behave on the job and that may influence their overall performance. Factor 2 items (items 1-3; Table 2) appear to 
TABLE 3

The Nomological Network: Correlations

\begin{tabular}{|c|c|c|c|c|}
\hline Variable & I. PC Org - Org Env & 2. PC Org - Job Env & 3. PC Emp - Dev & 4. PC Emp - Perf \\
\hline 2. PC organisation - Job environment & $.68^{* *}$ & & & \\
\hline 3. PC employee - Development & .21 & $.26^{*}$ & & \\
\hline 4. PC employee - Performance & $.31^{* *}$ & .13 & $.30^{* *}$ & \\
\hline Career plateau & $-.37^{* *}$ & $-.45^{* *}$ & $-.35^{* *}$ & -.12 \\
\hline Intention to quit & -.21 & $-.27^{*}$ & -.03 & .11 \\
\hline Affective commitment & $.34^{* *}$ & $.41^{* *}$ & $.31^{* *}$ & .08 \\
\hline Continuance commitment & -.16 & -.21 & $-.29^{* *}$ & $-.26 *$ \\
\hline Normative commitment & $.25^{*}$ & $.23^{*}$ & .20 & -.04 \\
\hline Job involvement & .09 & -.03 & .02 & -.15 \\
\hline Perceived organiaational support & $.51^{* *}$ & $.70^{* *}$ & .12 & .07 \\
\hline Job satisfaction & $.42^{* *}$ & $.53^{* *}$ & $.29^{* *}$ & $.24^{*}$ \\
\hline Person-Organisation fit & $.33^{\text {** }}$ & $.40^{* *}$ & $.22 *$ & $.26^{*}$ \\
\hline Work involvement & .03 & -.01 & -.14 & $-.23^{*}$ \\
\hline
\end{tabular}

Note: ${ }^{* k}=$ Significant at $p=.01$

$*=$ Significant at $p=.05$

relate to obligations that officers believe they have toward pursuing their own development. Based on this analysis, two variables were constructed. The first variable (Factor 1), containing 14 items, was termed 'psychological contract - employee performance' (PC-Pfm, $a=.90$ ). The second variable (Factor 2), containing three items, was termed 'psychological contract — employee development' (PC-Dev, $a=.78$ ).

Construct validation. The factor structure revealed in the analysis of the items relating to the extent to which obligations were believed to exist was imposed on the items relating to the extent to which participants believed the obligations were being fulfilled. This action resulted in four separate measures, assessing the extent to which officers believed the psychological contract was being fulfilled, being embedded into the nomological network of variables as previously defined: PC-OrgEnv, $(a=.90)$; PC-JobEnv, $(a=.70)$; PC-Dev, $(a=.78)$; PCPfm, $(a=.90)$. Within the network it was hypothesised that the extent to which participants believed that the psychological contract was being fulfilled would be positively related to organisational commitment, job involvement, perceived organisational support, job satisfaction, person-organisation fit, and work involvement, and negatively related to career plateau and intention to quit. The extent to which these hypothesised relationships were confirmed in this study provides strong evidence to argue for the construct validity of the measure (Freese \& Schalk, 2008).

The nomological network and fulfilment of the psychological contract. The correlations relevant to the assessment of the nomological network are presented in Table 3. Significant relationships were found between at least one of the four components of the psychological contract and all variables in the nomological network, with the exception of job involvement. As predicted, various components assessing fulfilment of the psychological contract were significantly related to career plateau, intention to quit, organisational commitment, perceived organisational support, job satisfaction, person-organisation fit, and work involvement but, against prediction, the relationships with work involvement and continuance commitment were negative. The nonsignificance of job involvement, and the negative relationships of work involvement and continuance commitment, may support the contention that the psychological contract varies by employment sector and that the use of generic measures may be problematic. However, based on the analysis of the nomological network, and despite the relatively small number of exceptions, the number of predicted and significant relationships that were found presents a strong argument for construct validity of this four-component measure of the psychological contract for frontline police officers.

\section{Discussion}

Much of the research to date involving the psychological work contract has relied on measures developed ad hoc and a priori by researchers and for which little evidence of construct validity has been established or presented (Freese \& Schalk, 2008). The present research addressed that situation by utilising an inductive approach to the development and validation of a measure of the psychological contract. This research has confirmed what frontline police officers believe is important to them regarding the content of their psychological work contracts. The 
research also confirmed that the measure developed is reliable and valid and may be used with confidence in assessing the psychological contract for this employment sector. Replication of this study within another sample of police officers would further reinforce the measure's validity.

Accepting Rousseau's (1989) and others (Morrison \& Robinson, 1997; Turnley, Bolino, Lester, \& Bloodgood, 2003) argument that the psychological contract is an individually constructed and perceived phenomenon, participants were relied upon to provide both their and the organisation's perspective (Goddard, 1984; Rousseau, 1995). Two views were captured: what the individual believed the organisation's obligations were, that is, their expectations; and what the individual believed the organisation expected from him or her in return, that is, their own obligations. These two views are grounded in the argument that a promise creates an obligation, which in turn creates an expectation of fulfilment by the other party.

Factor analysis revealed two factors for each component, the organisation's obligations and the employee's obligations, of the measure. There is debate in the literature over the view that psychological contracts generally comprise transactional and relational components (see, e.g., Conway \& Briner, 2005; Crossman, 2004), and this typology was not specifically identifiable in this particular study. The two factors in the organisation's obligations component suggest a differentiation on the part of frontline police officers between the environment in which the job itself is performed (e.g., interesting and satisfying job, job security) and the general organisational environment (e.g., safe working environment, fair and equitable treatment). Whether this differentiation may be viewed as transactional versus relational is an individual perspective.

The two factors that emerged from the employee's obligations components suggest a differentiation between the individual pursuing development (e.g., career development and training opportunities) and engaging in behaviours that potentially influence their overall job performance (e.g., perform job to utmost ability, personal ethics and integrity). Again, whether this differentiation may be viewed as transactional versus relational is an individual perspective. It could be argued, for example, that development has more impact on the individual (transactional), whereas the performance component may have more influence on the employment relationship (relational).

How the idiosyncratic content of the psychological contract may be measured in practice remains an issue to be faced by both researchers and practitioners. Although measures that capture the commonalities of content for a specific and identified employment group can be developed, such measures may exclude the obligations and expectations arising from promises, explicit or implicit, idiosyncratic to an individual. As both Kotter (1973) and Sims (1994) speculated, the psychological contract may literally contain thousands of items. Condensing these items into a practical measure for any employment sector will inevitably result in some loss of idiosyncratic content.

Despite the loss of idiosyncratic content, a measure has been developed that captures the important content of the psychological contract for frontline police officers and against which other measures may be compared and/or validated. In doing so, an understanding of the content of psychological contracts has been furthered. As ongoing research into content focuses on different samples, the extent to which content varies across those samples will become evident.

\section{Limitations}

The sample size $(N=84)$ may influence the extent to which the results may be generalisable to other similar samples. Additionally, the low response rate may have introduced a positive bias to the data (see for example Dreher, 1977; Rogelberg, Luong, Sederburg, \& Cristol, 2000), further restricting generalisability. Although the sample size was slightly outside the range of $N=100$ to 200 for models with well-determined factors (MacCallum, Widaman, Zhang, \& Hong, 1999), and resulted in a low cases-to-items ratio, the factor analyses produced reliable factors. That this research included only frontline police officers from one country (NZ) may also restrict its applicability and the extent to which the results may be generalised to other police samples, or to police from other countries.

\section{Future Research}

The underlying premise of this research was that the content of psychological contracts varies across several factors at societal, organisational, and individual levels (Conway \& Briner, 2005; Dabos \& Rousseau, 2004; McLean Parks, et al., 1998; Rousseau \& Tijoriwala, 1998; Thomas, et al., 2003). Confirming whether or not this premise has foundation potentially opens up a kaleidoscope of opportunities for researchers to pursue continuing research into the content of the psychological contract. Psychological work contracts are studied because of the impact that breach or violation (nonfulfilment) of those contracts has on the employment relationship, although there is increasing interest in also understanding the effects of psychological contract fulfilment and overfulfilment (Ho, 2005; Kotter, 1973; Lambert, Edwards, \& Cable, 2003). Research indicates that when the psychological contract is violated, the attitudes and behaviours of individuals are negatively affected, with a consequential impact on organisational functioning. Having valid and specific measures will lead to a greater understanding of the effect that contract fulfilment may have on an individual's attitudes and behaviours. 


\section{Conclusion}

The content of psychological contracts is proposed to vary by, among other factors, employment level. This may be illustrated by comparing the potential content of the contract for a police officer versus the potential content of the contract for a factory worker. The expectations each would have, and therefore the obligations they believed the organisation would have toward them, would differ. Although this research indicates that much of the content of psychological contracts for frontline police officers may, at an aggregated level, be reasonably common for these employees, and provides the items that may be included in a measure to assess fulfilment of the contract, the relevance or strength of specific items may vary depending on individual circumstances or expectations.

What emerges is the likelihood that although researchers may be able to develop psychological contract measures that represent specific groups of employees, ultimately what is in an individual's psychological contract, and the relevance of that content is very much an individual construction. So, although measures may be developed that will contain content of common interest to specific groups of workers, there will always be items of specific interest to individuals that may be excluded from those measures. This highlights the idiosyncratic nature of psychological contracts as discussed by many authors (Freese \& Schalk, 1996; Kotter, 1973; McLean Parks et al., 1998; Sims, 1994).

An understanding of the consequences of contract fulfilment, or conversely breach or violation, of the psychological contract drives the ongoing research interest in the phenomenon. That research will be more credible and more applicable when it utilises measures of the psychological contract that have established validity and acknowledge the many influences on the formation of content.

\section{References}

Anderson, N., \& Schalk, R. (1998). The psychological contract in retrospect and prospect. Journal of Organisational Behavior, 19, 637-647.

Blau, G.J. (1987). Using a person-environment fit model to predict job involvement and organisational commitment. Journal of Vocational Behavior, 30, 240-257.

Bozeman, D.P., \& Perrewe, P.L. (2001). The effect of item content overlap on organizational commitment questionnaire-turnover cognitions relationships. Journal of Applied Psychology, 86(1), 161-173.

Breakwell, G.M., Hammond, S., \& Fife-Schaw, C. (2000). Research Methods in Psychology (2nd ed.). London: Sage.

Cable, D.A.J. (1999). Plateau and transition: Career dynamics in a changing world of work (Unpublished masters thesis). Massey University, New Zealand.

Cable, D.A.J. (2010). A methodological approach to developing a measure of the psychological contract for managers. The Aus- tralian and New Zealand Journal of Organisational Psychology, 3, 21-31.

Cable, D.M., \& Judge, T.A. (1996). Person-organization fit, job choice decisions, and organizational entry. Organizational Behavior and Human Decision Processes, 67(3), 294-311.

Cavanaugh, M.A., \& Noe, R.A. (1999). Antecedents and consequences of relational components of the new psychological contract. Journal of Organizational Behavior, 20, 323-340.

Chao, G.T. (1990). Exploration of the conceptualization and measurement of career plateau: A comparative analysis. Journal of Management, 16(1), 181-193.

Clark, M.C., \& Payne, R.L. (1997). The nature and structure of worker's trust in management. Journal of Organizational Behavior, 18, 205-224.

Clinton, M., \& Guest, D.E. (2004, January). Fulfilment of the psychological contract and associated work attitudes: The role of fairness and trust. Paper presented at the BPS Division of Occupational Psychology Conference, Stratford, UK.

Conway, N., \& Briner, R.B. (2002). Full-time versus part-time employees: Understanding the links between work status, the psychological contract, and attitudes. Journal of Vocational Behavior, 61, 279-301.

Conway, N., \& Briner, R.B. (2005). Understanding psychological contracts at work. A critical evaluation of theory and research. New York: Oxford University Press.

Cook, J.D., Hepworth, S.J., Wall, T.D., \& Warr, P.B. (1981). The experience of work. London: Academic Press.

Coyle-Shapiro, J.A., \& Kessler, I. (2000). Consequences of the psychological contract for the employment relationship: A large scale survey. Journal of Management Studies, 37(7), 903-930.

Crossman, A. (2004). Critical incidents and the dynamics of the psychological contract. The Anahuac Journal, Spring/Summer, 55-66.

Dabos, G.E., \& Rousseau, D.M. (2004). Mutuality and reciprocity in the psychological contracts of employees and employers. Journal of Applied Psychology, 89(1), 52-72.

Dreher, G.F. (1977). Nonrespondent characteristics and respondent accuracy in salary research. Journal of Applied Psychology, 62(6), 773-776.

Eisenberger, R., Cummings, J., Armeli, S., \& Lynch, P. (1997). Perceived organizational support, discretionary treatment, and job satisfaction. Journal of Applied Psychology, 82(5), 812-820.

Eisenberger, R., Stinglhamber, F., Vandenberghe, C., Sucharski, I.L., \& Rhoades, L. (2002). Perceived supervisor support: Contributions to perceived organizational support and employee retention. Journal of Applied Psychology, 87(5), 565-573.

Ettington, D.R. (1998). Successful career plateauing. Journal of Vocational Behavior, 52, 72-88.

Freese, C., \& Schalk, R. (1996). Implications of differences in psychological contracts for human resource management. European Journal of Work and Organizational Psychology, 5(4), 501-509.

Freese, C., \& Schalk, R. (2008). How to measure the psychological contract? A critical criteria-based review of measures. South African Journal of Psychology, 38(2), 269-286.

Goddard, R.W. (1984). The psychological contract. Management World, 13(7), 12-14.

Hair, J.F., Anderson, R.E., Tatham, R.L., \& Black, W.C. (1995). Multivariate data analysis (4th ed.). Englewood Cliffs, NJ: Prentice Hall.

Herriot, P., \& Pemberton, C. (1997). Facilitating new deals. Human Resource Management Journal, 7(1), 45-56. 
Ho, V.T. (2005). Social influence on evaluations of psychological contract fulfillment. Academy of Management Review, 30(1), $113-128$

Jewel, L.N. (1998). Contemporary industrial/organizational psychology (3rd ed.). Pacific Grove, CA: Brooks/Cole Publishing Coy.

Kanungo, R.N. (1982). Measurement of job and work involvement. Journal of Applied Psychology, 67(3), 341-349.

Kelly, J.F. (1985). Coping with the career plateau. Personnel Administrator, 30(10), 65-76.

Kessler, I., \& Undy, R. (1996). The new employment relationship: Examining the psychological contract. London: IPD.

Kickul, J., \& Lester, S.W. (2001). Broken promises: Equity sensitivity as a moderator between psychological contract breach and employee attitudes and behavior. Journal of Business and Psychology, 26(2), 191-217.

Kline, P. (2000). An easy guide to factor analysis. London: Routledge.

Korsgaard, M.A., Brodt, S.E., \& Whitener, E.M. (2002). Trust in the face of conflict: The role of managerial trustworthy behavior and organizational context. Journal of Applied Psychology, 87(2), 312-319.

Kotter, J.P. (1973). The psychological contract: Managing the joining-up process. California Management Review, 15, 91-99.

Kramer, R.M. (1999). Trust and distrust in organizations: Emerging perspectives, enduring questions. Annual Review of Psychology, 50, 569-598.

Kristof, A.L. (1996). Person-organization fit: An integrative review of its conceptualizations, measurement, and implications. Personnel Psychology, 49(1), 1-49.

Lambert, S.J., Edwards, J.R., \& Cable, D.M. (2003). Breach and fulfilment of the psychological contract: A comparison of traditional and expanded views. Personnel Psychology, 56(4), 895933.

Locke, E.A. (1983). The nature and causes of job satisfaction. Chicago: Rand Nally.

Lynch, P.D., Eisenberger, R., \& Armeli, S. (1999). Perceived organizational support: Inferior versus superior performance by wary employees. Journal of Applied Psychology, 84(4), 467483.

MacCallum, R.C., Widaman, K.F., Zhang, S., \& Hong, S. (1999). Sample size in factor analysis. Psychological Methods, 4(1), 8499.

McLean Parks, J., Kidder, D.L., \& Gallagher, D.G. (1998). Fitting square pegs into round holes: Mapping the domain of contingent work arrangements onto the psychological contract. Journal of Organizational Behavior, 19, 697-730.

Meyer, J.P., \& Allen, N.J. (1997). Commitment in the workplace: Theory, research, and application. Thousand Oaks, CA: Sage Publications.

Morrison, E.W., \& Robinson, S.L. (1997). When employees feel betrayed: A model of how psychological contract violation develops. Academy of Management Review, 22(1), 226-256.

Mowday, R.T., Koberg, C.S., \& McArthur, A.W. (1984). The psychology of the withdrawal process: A cross-validational test of Mobley's intermediate linkages model of turnover in two samples. Academy of Management Review, 27(1).

Muchinsky, P.M. (2006). Psychology applied to work (8th ed.). Belmont, CA: Wadsworth/Thomson.

Murphy, K.R., \& Davidshofer, C.O. (1998). Psychological testing: Principles and applications (4th ed.). Upper Saddle River, NJ: Prentice Hall.

Paterson, J.M., \& O’Driscoll, M.P. (1990). An empirical assessment of Kanungo's (1992) concept and measurement of job involvement. Applied Psychology: An International Review, 39(3), 293-306.

Paullay, I.M., Alliger, G.M., \& Stone-Romero, E.F. (1994). Construct validation of two instruments designed to measure job involvement and work centrality. Journal of Applied Psychology, 79(2), 224-228.

Rhoades, L., Eisenberger, R., \& Armeli, S. (2001). Affective commitment to the organization: The contribution of perceived organizational support. Journal of Applied Psychology, 86(5), 825-836.

Robinson, S.L. (1996). Trust and breach of the psychological contract. Administrative Science Quarterly, 41, 574-599.

Rogelberg, S.G., Luong, A., Sederburg, M.E., \& Cristol, D.S. (2000). Employee attitude surveys: Examining the attitudes of non-compliant employees. Journal of Applied Psychology, 85(2), 284-293.

Rousseau, D.M. (1989). Psychological and implied contracts in organizations. Employee Responsibilities and Rights Journal, 2(2), 121-139.

Rousseau, D.M. (1995). Psychological contracts in organizations. Thousand Oaks, CA: Sage Publications.

Rousseau, D.M. (1998). The 'problem' of the psychological contract considered. Journal of Organizational Behavior, 19, 665671.

Rousseau, D.M., \& Tijoriwala, S.A. (1998). Assessing psychological contracts: Issues, alternatives and measures. Journal of Organizational Behavior, 19, 679-695.

Sims, R.R. (1994). Human resource management's role in clarifying the new psychological contract. Human Resource Management, 33(3), 373-382.

Tett, R.P., \& Meyer, J.P. (1993). Job satisfaction, organizational commitment, turnover intention, and turnover: Path analyses based on meta-analytic findings. Personnel Psychology, 46, 259293.

Thomas, D.C., Au, K., \& Ravlin, E.C. (2003). Cultural variation and the psychological contract. Journal of Organizational Behavior, 24, 451-471.

Turnley, W.H., Bolino, M.C., Lester, S., \& Bloodgood, J.M. (2003). The impact of psychological contract fulfillment on the performance of in-role and organizational citizenship behaviors. Journal of Management, 29(2), 187-206.

Westen, D., \& Rosenthal, R. (2003). Quantifying construct validity: Two simple measures. Journal of Personality and Social Psychology, 84(3), 608-618. 